\title{
Basic School Teachers' Conceptions of Assessment in the Sissala East Municipality
}

\author{
Shani Osman ${ }^{1 *}$, Anthony Bordoh ${ }^{2}$ and Isaac Eshun ${ }^{3}$ \\ ${ }^{1}$ Department of Social Sciences, Tumu College of Education, Tumu, Ghana \\ ${ }^{2,3}$ Department of Social Studies, University of Education, Winneba, Ghana \\ Corresponding Author*
}

\begin{abstract}
This study employed a sequential explanatory mixedmethod design to examine basic school teachers' classroom assessment conceptions in the Sissala East Municipality in the Upper West Region of Ghana. In particular, the study examined the types of classroom assessment conceptions of teachers and their demographic characteristics that influence their assessment conceptions. Quantitative data gathered from 203 respondents were analyzed using mean, standard deviations and Pearson product-moment correlation. In the follow-up qualitative phase, semi-structured interviews were undertaken with 12 participants and the data subjected to interpretive thematic analysis. The findings revealed that the participants demonstrated positive conceptions of assessment as a means for ensuring student and school accountability as well as improving teaching and learning, with assessment for student accountability yielding the highest mean value. Also, the findings revealed that the relationships among student accountability, school accountability and improvement were moderate and that these levels have a positive effect on one another. It was recommended, among other issues, that teachers need to note that assessment is acceptable if motivated by a particular reason, whether it is for improvement, student accountability, or school accountability.
\end{abstract}

Key words: conceptions, assessment, conception of assessment, Sissala East, basic school teachers

\section{INTRODUCTION}

A ssessment of students' learning is pivotal in any educational enterprise; as such, teachers cannot avoid assessing their students. Assessment has been explained or defined variously. According to Nitko (2001) cited in Okyere and Larbi (2019), assessment involves collecting information purposely to make decisions on students' learning, curricula, programmes, and educational policy. Brown (2011) describes assessment as a mechanism of interpreting information regarding student achievement using a range of approaches or practices.Similarly, the National Council for Curriculum and Assessment

(NaCCA) (2019) notes that assessment is "a process of collecting and evaluating information about learners and using the information to make decisions to improve their learning" (p.27). From the above, assessment is pivotal in any instructional process.

Assessment could be carried out to serve accountability purposes for ascertaining the extent to which students have learned or plan and improve instruction in educational contexts (Danielson, 2008, cited in Azis, 2015). These two purposes occasionally complement one another and sometimes contend or contrast with each other, making classroom assessment an intricate process (Earl, 2003).

There may be several factors that influence the planned assessment practices of teachers. For instance, the individual conceptions of assessment by itself and their varied purposes may influence their judgment on what assessment method that they will use in their classrooms. Teachers' conceptions may have implications for how they believe that their students learn (Brown, 2002). Conceptions of assessment denote "the belief systems that teachers have about the nature and purposes of assessment, and that encompasses their cognitive and affective responses" (Xu \& Brown, 2016, p. 56). Brown has uniquely researched teachers' assessment conceptions. Brown (2002; 2004; 2006; 2008) noted that the conceptions teachers hold of assessment can be categorized under the following: (1) strengthening instruction and learning (Improvement); (2) ensuring learners are responsible for their progress in learning (student accountability); (3) making teachers and schools accountable (school accountability), and; (4) irrelevant and of no consequence to the activities of teachers and learners (irrelevance).

The conceptions of assessment teachers hold are of great consequence as they influence their assessment practices (Harris \& Brown, 2009). Moiinvaziri (2015) opined that the techniques teachers employ in assessing students' learning differ depending on their notion of assessment, teaching and learning. As a result, according to Brown, Lake and Matters (2011), it is essential to consider teachers' assessment beliefs to appreciate their practices well and, if necessary, find ways to improve their assessment practices. According to Brown (2008), teachers' positive notions of assessment such as assessment improve students' learning have given rise to useful assessment practices; whiles their negative views of assessment of not relevant to students learning can contribute significantly to their acceptance of assessment reforms.

Studies have confirmed that teachers' conceptions of assessment influenced their assessment methods and usage (Azis, 2015; Brown, 2009; Dayal\& Lingam, 2015). Also, Brown and Harris (2009); and Brown, Lake, and Matters (2009, 2011), have established that societies' policies and cultural priorities influence teacher' conceptions, hence 
teachers' conceptions vary from one society to another. Hence it is necessary to determine how teachers, especially in the Ghanaian context, conceive and utilize assessment.

Assessment topics are not as much investigated and researched in the Ghanaian context. Curriculum planners and assessment experts may perhaps not empirically well-versed on how teachers conceive assessment. For this reason, when these assessment experts and curriculum designers devise their guidelines and policies for assessment, the set guidelines may probably not wholly correspond with teachers' assessment beliefs, which invariably impact their practices, hence will affect the achievement of intended curricular goals and visions.

In Ghana, studies on assessment and its practices among teachers have been well researched and documented (e.g. Amedahe, 1989; Amoako, 2018; Bordoh, Bassaw \& Eshun, 2013). However, the researches in this area focused attention on teachers' grading practices (Amedahe, 1989; Anhwere, 2009), senior high school teachers formative assessment practices and their impact on students learning (Sofo, Ocansey, Nabie \& Asola, 2013), among Colleges of Education tutors and the strategies they use (Bekoe, Eshun \& Bordoh, 2013; Eshun, Bordoh, Bassaw \& Mensah, 2014), among distance education tutors (Amoako, 2018) as well as among Kindergarten school teachers in the country (Asare, 2015). These investigations have not particularly paid attention to assessment conceptions teachers hold for their practices, specifically in the Ghanaian educational system.

Besides, the studies on conceptions of assessment have typically employed quantitative surveys that do not integrate the participants' voices to explain their conceptions. This means that quantitative findings may not completely depict and clarify teachers' assessment beliefs and practices.

Therefore, this study aspires to deal with the research gaps identified above by using mixed-methods to explore the conceptions and practices basic school teachers (Primary and Junior High) hold about classroom assessment within a Ghanaian context.

\section{Research Questions}

The research questions which guided the study were:

1. How do basic school teachers in the Sissala East Municipality conceive of assessment?

2. Are they any relationship among the teachers' conception of assessment?

\section{LITERATURE REVIEW}

\section{Meaning of Conception of Assessment}

Whiles some authors such as Remesal (2011) make a distinction between the terms 'conceptions' and 'beliefs', others such as Calveric (2010), Vardar (2010), Yidana and Anti Partey (2018) choose to use the two terms interchangeably. However, Brown (2004, 2008) and
Thompson (1992) prefer the term 'conceptions' rather than 'beliefs'. There are different views among educational researchers on a working definition of conceptions. However, the term "conception" in this study has been drawn from Brown's (2004, 2008) and Thompson's (1992) definitions of conception. Brown (2004) explains conceptions as "the organizing framework by which an individual understands, responds to, and interacts with a phenomenon" (p.303). Thompson (1992) explains conceptions "as a more general mental structure, encompassing beliefs, meanings, concepts, propositions, rules, mental images, preferences, and the like" (p. 130). According to Brown and Gao (2015), conceptions denote "the ideas, values and attitudes people have toward what something is (i.e. what they think it is and how it is structured) and what it is for (i.e. its purpose)" (p. 4). Thus, the term conception fuses knowledge and belief into one construct and therefore eliminates the operational challenges researchers face when they try to make distinguish between beliefs and conceptions (Barnes, Fives \& Dacey, 2015; Barnes, Fives \& Dacey, 2017). According to Opre (2015), "if we are to refer to teachers' beliefs about assessment, the preferred term and the most frequently used in the specialized literature is that of conceptions" (p. 230).

Barnes, Fives and Dacey (2015) and Azis (2015) reviewed empirical articles allied to this subject matter and subsumed teachers' assessment conceptions as existing on a continuum. They range from an 'extreme pedagogical' point of view or assessment for learning with the focus that assessment is for advancing students learning and improving teaching at one end, to 'extreme accountability' purposes or assessment of learning with the focus that assessment hold schools accountable for students learning at the other side of the continuum. These studies examining teachers' assessment conceptions encompass diverse research objectives, methodology and participants.

Although there are numerous available frameworks that depict likely conceptions of assessment (e.g., Davis \& Neitzel, 2011; Harris \& Brown; 2009; Remesal, 2011), the emphasis of this study is on the use of Brown (2004, 2006), Conceptions of Assessment (CoA-III), devised from existing studies to illustrate the purposes of assessment. Teachers in New Zealand and Australia were used in the initial studies using this instrument, but further studies have been replicated in several international contexts. The original instrument with a 6-point agreement rating scale consisted of 50 Likert- type items. Subsequently, Brown (2006) validated a 27-items abridged version (Conceptions of Assessment Abridged, CoAIIIA). The framework provides four inter-correlated conceptions of assessment or purposes of assessments categorized as one 'anti-purpose' and three 'purposes'. The three purposes are: (1) improvement (assessment promotes teaching and learning assessment); (2) student accountability (assessment ensures that students account for their learning and; (3) school Accountability (assessment makes schools and teachers accountable for students' learning). The fourth 
purpose or the anti-purpose represents the idea that assessment is basically of no significance (Irrelevant). However, by aligning the student and school accountability purposes, it is likely to contend that two main assessment purposes of improvement and accountability exist in every society.

According to Harris (2008), apart from the first conception, the remaining three conceptions are linked with assessment practices referred to as summative. Brown's theoretical perspective for the developing this scale is that teachers can and do hold contradictory or conflicting conceptions as teachers usually view assessment as fulfilling different purposes. In other words, teachers can concurrently hold multiple assessment conceptions. For instance, Brown (2004) reported that New Zealand teachers simultaneously held the assessment conceptions of improvement and school accountability. The model was subsequently adapted to suit Asian environments by adding examination as another vital element to suit high-stakes assessment backgrounds (Brown, Lake \& Matters, 2009). Each of the four conceptions is further explained below.

The improvement conception originates from the perspective of 'assessment for learning' or 'formative assessment'. According to Brown (2006), teachers regard assessment as promoting or advancing their teaching and students' learning. For this reason, the improvement conception of assessment can be equated to "formative assessment" or "assessment for learning" (Brown, Lake, \& Matters, 2011). Here, the primary role of assessment is strengthening teaching and learning by applying formative assessment techniques and strategies to provide relevant feedback to the instructor and the learner.

The student accountability conception is of the perspective that assessment holds students accountable by demanding that students individually assume control of their learning in acquiring the necessary credentials to advance to various levels of education. In this case, employers and parents are the main beneficiaries of this kind of assessment information. Brown (2002) noted that students' accountability implies that "the students are individually accountable for their learning through their performance on assessment" (p. 40). Moiinvaziri (2015) stated that the student accountability conception connotes assessment is used to verify learners' achievement on pre-established standards.

The school accountability conception subsumes assessment as a mechanism through which teachers and schools are kept accountable for their students' progress. It thus implies that when assessment is made to keep students accountable, it is also used to assess schools' and teachers' performance by holding the two answerable for students' shortcomings in their performance. Moiinvaziri (2015) noted that school accountability conception alludes to "the use of assessment to see how well teachers or schools are doing in relation to the established standards" (p. 76).

The fourth conception, the conception of irrelevance, rejects the purpose of assessment and thus subscribe to the conviction that assessment has no logical place in the students' lives and teachers work. This can be referred to as an "anti-purpose of assessment". This notion is premised on the observation that assessment is inaccurate and unreliable and hence has no usefulness to teachers and students but rather harms them (Brown, 2002, 2004; Harris, 2008). This conception holds that assessment is unreliable, bad, inaccurate, and must be ignored (Brown et al., 2011).

\section{Empirical Studies on Teachers' Conceptions of Assessment}

Several studies spanning many cultures, educational systems and jurisdictions have utilised both the full and abridged form of TCoA-III. Using the full version of the TCoA-III, Brown (2004) examined 525 primary teachers' assessment conceptions in New Zealand. According to Brown (2004), the study was conducted at a period when assessment in New Zealand was focused woven on low-stakes classroom-based assessment with emphasis placed on "voluntary, school-based assessment for the purpose of raising achievement and improving the quality of teaching programmes" (p.306). The results revealed an acceptance of the school accountability and improvement conceptions by the teachers with the improvement conceptions as the primary reason for classroom assessment. The conceptions that assessment is irrelevant and assessment holds students accountable were rejected by the teachers. It was unsurprising that the New Zealand primary teachers endorsed the improvement conception of assessment because the assessment for learning practices was at that time ingrained at the primary level. The study findings also revealed a moderate positive correlation $(\mathrm{r}=.58)$ between school accountability and improvement conceptions. This implies that teachers who endorsed the improvement conception of assessment were more likely to consent to the school accountability notion of assessment. According to Brown (2004), this is attributable to the situation in New Zealand in which teachers were "accountable to their colleagues and to a school-based board of trustees made up of parents of pupils for the effectiveness of their work in changing student learning outcomes" (p.313).

Using a Chinese Translated version of the TCoA inventory and Practices of Assessment Inventory (PrAI), Brown, Kennedy, Fok, Chan \& Yu (2009) examined the assessment practices and conceptions of 300 teachers in Hong Kong. The results show that Hong Kong teachers use assessment practices to help their students achieve higher academic success (Brown et al., 2009). Furthermore, student accountability and improvement were strongly correlated ( $\mathrm{r}$ $=.91$ ). This means that ensuring students accountable for their learning also improves their learning.

Brown, Hui, Yu and Kennedy (2011) employed a contextspecific edition of Brown's (2006) TCoA inventory with two new constructs to investigate the Chinese context further involving 912 teachers from Guangzhou $(n=898)$ and Hong Kong $(n=1014)$. An analysis of the results showed a hierarchical three-factor model of conceptions of assessment - 
irrelevance, accountability and improvement. Also, accountability and improvement conceptions were strongly correlated $(\mathrm{r}=.80)$. This finding was in harmony with Brown et al (2009); hence they noted that the results once more buttress the effect of "the Chinese tradition and policy of using examinations to drive teaching quality and student learning and as a force for merit-based decisions" (p.307).

In Turkey, Vardar (2010) examined sixth to eighth-grade Turkish teachers' ( $n=414)$ assessment conceptions using the TCoA-IIIA. The study findings indicated that the teachers held students' accountability conceptions as the utmost priority. Vadar (2010) attributed this to the Turkish high-stakes education culture that puts students in a competitive manner in obtaining higher grades examinations. Also, improvement, student accountability, and school accountability conceptions correlated significantly at a moderate level at each other. This implies that the teachers "conceived of assessment as assigning a grade or placing students into categories in order to increase their students' scores in assessments" (Vadar, 2010, p. 69). However, there was no significant relationship between Irrelevance conception with other conceptions. Irrelevance conceptions recorded the lowest mean score implying that "assessment was not seen as irrelevant in teaching and learning environment by these teachers" (Vadar, 2010, p. 70).

In New Zealand, Brown (2011) compared 573 primary and 404 secondary school teachers' assessment conceptions. The findings showed that teachers in both samples did not differ in their endorsement levels for school accountability, improvement, and irrelevance conceptions. However, a statistically significant gap in mean ratings was observed in student accountability conception, with the secondary teachers endorsing it. Brown (2011) attributed it to the secondary school teachers' constant engagement in assessing their students based on the requirements of the state examination system.

Similarly, Brown, Lake and Matters (2011) using the TCoAIIIA investigated Queensland's primary $(n=784)$ and secondary $(n=614)$ teachers' assessment conceptions. Brown et al. (2011) reported that the system of assessment practices in Queensland was similar to New Zealand where assessment practices are of low stakes nature at the primary and lower secondary schools and high stakes in the last two years of secondary school. The findings revealed that the primary teachers endorsed improvement conception as the principal function of assessment; whiles the secondary teachers endorsed the student accountability conception. This result coincides with the New Zealand research by Brown (2011). Also, school accountability correlated moderately with improvement and student accountability. Hence, Brown et al (2011) concluded that "accountability at the school level, assessing students and improvement were intertwined rather than juxtaposed" (p.217).
Brown and Michaelides (2011) investigated primary and secondary school teachers' conceptions of assessment from New Zealand and Cyprus. The study examined the validity of the New Zealand TCoA-IIIA model with Greek-Cypriot teachers. In terms of assessment culture, both countries have low-stakes improvement-oriented assessment policies; therefore, predicated on the premise of ecological rationality, it was anticipated that teachers from both countries would have similar assessment conceptions. Confirmatory factor analysis showed that the Cyrus data did not fit the New Zealand model. The results revealed an inter-correlated model of positive and negative conceptions of assessment. The positive conception orientation towards assessment comprises three subsidiary factors (improving student learning, improving teaching, and holding schools accountable). Two subordinate factors consisted of the negative conception (assessment is bad, and assessment is ignored). The findings revealed that the Cypriot teachers approved, to a greater extent, the positive conception of assessment than the negative one. The findings also revealed similar ratings for "teacher improvement", "student learning", and "bad" factors in both Cyprus and New Zealand. This implies that some similarities exist across cultures in terms of teachers' assessment conceptions. The authors noted that both countries have similar moderately low-stakes assessment policies regarding school accountability and improvement. The authors also indicated that the more endorsement of school accountability by the Cypriot teachers than the New Zealand teachers is highly probably related to the Cypriot system of education.

In a related study to Brown and Michaelides (2011) in Cyprus, Segers and Tillema (2011) conducted a study of Dutch secondary teachers $(n=351)$ using the TCoA-IIIA. An exploratory factor analysis revealed a four-factor model that partially validates Brown's (2006) study. The Dutch secondary teachers expressed four main conceptions of assessment as; informing performance and learning, holding schools accountable, imprecise with measurement errors, and making instructional decisions and measures of higher-level thinking skills. The findings indicated that teachers failed to distinguish between formative and summative assessment functions. The authors viewed this as a manifestation of the Netherlands' secondary school system that uses assessments for both formative and summative purposes.

Gebril and Brown (2014) examined 202 practising teachers and 305 pre-service teachers' conceptions of assessment in Egypt using an Arabic translation version of the TCoA-IIIA. As in the case of China, the education system in Egypt is also examination-based at all educational levels, characterized by summative assessments for the selection of students for further studies. Confirmatory factor analyses of the teachers' conception of assessment indicated a three-factor model of conceptions - improvement, school accountability, and irrelevance. The teachers in both groups certified the improvement conception as the highest priority. The findings also revealed improvement conception correlated strongly 
with school accountability $(\mathrm{r}=.89)$. The strong correlation between the improvement and school accountability is harmonious with earlier findings in the Chinese context from studies by Brown et al. (2009) and Brown et al. (2011). This finding is in tandem with ecological rationality as a result of the high-stakes setting in Egypt.

Using the TCoA-II, Brown, Chaudhry and Dhamija (2015) examined the conceptions of assessment of 1,645 Northern Indian secondary school teachers. A confirmatory and exploratory analysis indicated that the teachers recognized assessment as a mechanism to control their teaching and lessons, for improvement, as a signifier of school quality, and irrelevant.

In another quantitative study, Yates and Johnston (2017) employed TCoA-IIIA (Brown, 2006) to examine 135 secondary teachers' assessment conceptions in New Zealand. The results from the study discovered a new factor assessment is for qualifications. This factor, according to Yates and Johnston (2017), is an indication of the ecological effect of "summative assessment for qualifications on high school teachers' conceptions of assessment" (p.15). Another finding of the study was the positive but weak relationships between the formative and summative assessment purposes. Yates and Johnston (2017) asserted that the correlations might "indicate a tendency for teachers to see a dual purpose for National Certificate of Educational Achievement (NCEA) school-based assessment" also, it might be a sign of "tensions between using assessment for both formative and summative purposes" (p.14). Furthermore, a fairly weak positive relationship was found between assessment school accountability assessment conception and assessment for qualifications $(\mathrm{r}=.165)$. With this, Yates and Johnson (2017) noted that the teachers somewhat endorsed the "notion that school quality can be measured through assessment results, in particular when those assessments are also used to award qualifications" (p.11). Concluding, Yates and Johnston (2017) noted that, on the whole, the sample of teachers in their study exhibited conceptions of assessment that are parallel to Brown (2011 but are more in line with the findings from high-stakes assessment contexts.

Barnes, Fives and Dacey (2017) investigated the assessment conceptions of K-12 teachers ( $\mathrm{n}=179)$ using TCoA-IIIA from a person-centred approach in the United States. In the US context, though there is no mandatory national examination, all public schools are mandated "to administer state wide assessments, typically implemented with a single standardized test, annually to students in order to receive national funding" (Barnes, Fives \& Dacey, 2017, p 110). Typically, teachers used classroom assessments for formative and summative purposes. An exploratory factor analysis found a three-factor model: improvement, accountability, and irrelevant. Further analysis results revealed that teachers simultaneously hold multiple assessment conceptions. The teachers showed that they regarded the purpose of assessment is for holding students, teachers and schools accountable, improving teaching and learning, and irrelevant to their work.

Implementing a non-experimental cross-sectional design, Darmody (2017) studied 489 post-primary teachers' assessment conceptions in Ireland using TCoA-IIIA. The study was aimed at establishing a reference point data about teachers' assessment conceptions in the mix of major assessment and curriculum reforms. Exploratory factor analysis resulted in a 5-element model that varied partially from Brown's (2006) version. The teachers conceived the purpose of assessment as a diagnostic and formative tool; irrelevant; makes school accountable; a measurement and categorization tool; and a valid grading tool. Darmody (2017) noted that the five factors "map readily onto a continuum of assessment purposes ranging from assessment for improvement purposes to assessment for grading and accountability purposes" (p. 120). According to Darmody (2017), these continua of factors as obtained in the Irish context lend credence to the assertion by Brown and Harris (2009) that 'teachers' conceptions of assessment are ecologically rational" (Darmody, 2017, p. 120). Also, the findings revealed a strong endorsement of assessment as 'a measurement and categorisation tool' and 'assessment as a diagnostic and formative tool'. There was a moderate positive correlation ( $\mathrm{r}=.30)$ between 'assessment as a measurement and categorisation tool', and 'assessment is a diagnostic and formative tool'. Additionally, there was no correlation between assessment is a diagnostic and formative tool and assessment is a valid grading tool. This contrasted sharply with previous studies conducted by Brown et al. (2009) and Brown et al. (2011) that indicated a clear correlation between the improvement conception of assessment and assessment for grading $(\mathrm{r}=.91 / \mathrm{r}=.80$ respectively).

Fulmer, Tan and Lee (2017) investigated 229 Singaporean secondary school teachers' assessment conceptions and related contextual factors. The results revealed a teachers' support for the assessment conception of improvement, student accountability, and school accountability and a rejection of the irrelevance conception of assessment.

Yetkin (2017) studied 204 pre-service English teachers' conceptions of assessment using TCoA-IIIA. The results revealed that the highest endorsement value was the improvement conception, and the lowest was the irrelevance conception. Also, there were strong and positive correlations among improvement, student accountability and school accountability conceptions. In contrast, a negative correlation was found between improvement and irrelevance conceptions.

In Ghana, Yidana and Anti Partey (2018) conducted a study involving 301 secondary school Economics teachers on their conception of assessment. The study adopted the 56-item version of TCoA inventory scale. The study findings revealed that the Economics teachers conceived classroom assessment to hold students accountable and responsible for their learning, improve teaching and learning, and assure school 
accountability. However, the irrelevance conception of assessment was rejected by the respondents.

While several studies adopted Brown's CoA - III to look at assessment conceptions quantitatively; many qualitative studies are available. Some of these studies attempt to understand the idea of assessment conceptions as defined by Brown (2002) with a qualitative lens. Employing a qualitative methodology, Remesal (2011) in a study of 50 Spanish teachers (30 primary and 20 secondary mathematics teachers), examined interview transcripts and artefacts and found four factors of assessment purposes and subsumed them onto a continuum of pedagogical to accounting purposes. Although these conceptions are similar to Brown, she propounded that her teachers' conceptions fell into a bi-polar continuum of pedagogical conceptions (assessment for monitoring teaching and learning) at one side and the other side an extreme societal-accreditation conception (assessment for certification of learning and teachers' accountability) and in between the poles some mixed conceptions (Remesal, 2011). The continuum is founded on four functions of assessment in learning, teaching, certification of learning and teaching accountability. The teachers' general conceptions of assessment were determined as follows. If a participant's beliefs could be put on one of the two poles for the four dimensions, that participant was marked as possessing an extreme pedagogical or extreme societal conception of assessment. Those whose opinions were distributed among the four elements in a 3:1 ratio were portrayed as having a mixed pedagogical or mixed social concept of assessment. According to the results, there were more than twice as many teachers with a mixed conception as there were with an extreme notion (i.e. 3:1 social or pedagogical). Remesal observed that this finding mirrors the multifaceted complexity of classroom assessment. While the primary teachers' conceptions were mostly pedagogical, the conceptions of secondary teachers were mostly mixed or pure societal conceptions. This result is aligned with the quantitative studies described above (Brown, 2011; Brown et al., 2011), which revealed that summative assessment held the highest priority among teachers at the secondary level. Regardless of their research discrepancies, both Remesal and Brown consent that; assessment could and should support instruction and learning processes. Also, Remesal's pedagogical conceptions (i. e., assessment for monitoring teaching and learning) align with Brown's improvement conception of assessment, that of the societal conceptions align with Brown's school accountability and student accountability conceptions.

Employing qualitative design, Haris (2008) examined 11 secondary Auckland teachers' conception of assessment and feedback. The study revealed that the purpose of assessment could be conceived in one of three key ways: improving student learning, making teachers and schools accountable to stakeholders by reporting students' performance, and detrimental or irrelevant to student learning. Contrary to Brown's (2006) study, the teachers did not subscribe to the belief that assessment gets students accountable in their learning, as envisaged by Brown. Instead, when it comes to assessment, the teachers reported being highly personally accountable for their students' successes and flops.

Sethusha (2012) used qualitative methods (semi-structured interviews, observations and document analyses) to examine teachers' (n-2) classroom assessment practices and conceptions.The results showed that assessment was essentially planned for improvement of teaching and learning and school accountability. Also, their practices were in tandem with the two conceptions. Another finding of the study was that the cultural and education system and teachers' personal experiences of assessment influenced their conceptions of assessment.

Employing qualitative methods, Dayal and Lingam (2015) studied the conceptions of assessment of 43 in-service and 27 pre-service Fijian teachers who were participating in an assessment module in a Fijian university. The results revealed that pre-service teachers mostly held an assessment of learning notion; in contrast, an assessment for learning conception was held by the majority of in-service teachers.

In a mixed study, Harris and Brown (2009) interviewed 26 New Zealand teachers from a sample of 161 participants thatfilled theTCoA-IIIA inventory to investigate their conceptions of the assessment purposes. This was to assess the TCoA instrument's ability to adequately assess a broad range of teachers' views about assessment purposes. Seven conceptions of assessment were identified, which included external reporting, compliance, reporting to parents, facilitating group instruction, extrinsically motivating students, teacher use for individualising learning, and joint teacher and student use for individualising learning. According to Harris and Brown (2009), the seven purposes can be put under three key assessment purposes - student improvement, accountability and irrelevance. Based on this finding, the authors viewed it as an independent confirmation for the factors in TCoA-IIIA (Brown, 2006). Reporting to parents, external reporting and extrinsically motivating students were all conceptually aligned with the perspective of accountability, with the reporting purposes specifically associated with school accountability and extrinsic motivation by grades and qualifications linked to student accountability. Furthermore, teacher use for individualising learning, joint teacher and student use for individualising learning and facilitating group instruction were subsumed under improvement purpose of assessment. The compliance purpose was regarded to be associated under the irrelevance conception. Moreover, the study demonstrated that teachers conceive assessment as having a multifaceted array of conflicting purposes. In this regard, teachers must consider harmonizing the desires of stakeholders such as the pupil, the school, and the society when embarking on classroom assessment. Some tensions emphasized in the study included those between student and school, and improvement and compliance. 
Using a questionnaire, semi-structured interviews, and document analysis, Azis (2014) studied 107 Indonesian junior high English teachers' assessment conceptions. The findings showed that the teachers conceived the purposes of classroom assessment as enhancing teaching and learning and to keeping students and school accountable. However, they rejected the irrelevance conception of assessment. Also, the findings indicated a high level of enthusiasm among teachers to apply assessment practices that aid and enhance their teaching; however, their efforts were hindered by state-wide examination policy. Similarly, in an Iranian context, Moiinvaziri (2015) employed a mixed-method design involving 147 university teachers. The study revealed that, amongst the majority of participants, the aim of assessment was to enhance the quality of teaching and learning.

\section{METHODOLOGY}

This study adopted Creswell and Creswell (2018), Creswell and Plano Clark (2018) and Johnson and Christensen (2017) sequential explanatory mixed methods design, which utilizes qualitative information to support an earlier quantitative result. The design commences with the quantitative data collection and analysis of data that have the priority to address the research objectives and then continues with a corresponding qualitative data collection and analysis. The investigator interprets how the qualitative findings help clarify the initial quantitative results (Creswell \& Plano Clark, 2018; Creswell $\&$ Creswell 2018). However, the main challenges of this design are on determining which qualitative results to use and the selection of samples for both phases (Creswell \& Creswell, 2018).

All 796 professional basic school teachers from the nine circuits in the Sissala East Municipality constituted this study population. Using Krejcie and Morgan's (1970) table for determining sample size, 260 teachers were sampled for the study. However, 224 teachers completed and returned the questionnaire resulting in about $86 \%$ returned rate. The researcher used multistage sampling methods. Multistage sampling involves splitting the population into phases, sampling the phases and then re-sampling, going over the process until the final level of the hierarchy is selected (Goldstein as cited in Nafiu, 2012). Thus, in multistage sampling, the sample population changes at each phase or stage of the research (Cohen, Manion \& Morrison, 2018). In the quantitative stage of the study, firstly, a convenience sampling technique was applied to select four (4) circuits with a population of 441 teachers. Convenience sampling technique is an approach where a sample is selected according to the researcher's suitability in respect of the availability of data, accessibility of the subjects, among others (Agyedu, Donkor \& Obeng, 2013; Cohen, Manion \& Morrison, 2018; Neuman, 2014). These four circuits were conveniently chosen due to their accessibility and proximity to the researcher. Secondly, all the basic school teachers in the four circuits were stratified into Lower Primary, Upper Primary and JHS and from which 260 teachers were purposively sampled. In purposive sampling, the investigator chooses the cases to be included in the survey based on the study purpose, and people of interest are chosen as a sample and leaving out those who do not meet the intent (Cohen, Manion \& Morrison, 2018).

Nested sampling (sample sampling) was used for the qualitative segment of the study to pick teachers. The criteria used were to classify all teachers who displayed the greatest agreement on the questionnaire items on assessment conceptions. The participants in this phase were purposively selected to reflect various assessment conception categories of respondents in the quantitative phase.

Data collection instruments were a questionnaire and an interview guide. The questionnaire consisted of 27 items on teachers' assessment conceptions. The items were adapted from Brown's (2006) Conceptions of Assessment III (TCoAIIIA) Abridged Survey. The teachers are requested to state their degree of agreement with statements concerning four overarching educational assessment purposes. This instrument has been utilized in studies in various countries, as stated previously, in the literature review such as Brown (2011), Segers and Tillema (2011), Brown and Michaelides (2011) and Gebril and Brown (2014). We used the validated TCoAIIIA (Brown, 2006) because we speculated that Ghanaian teachers could have related conceptions to teachers in other jurisdictions.

The Statistical Product for Service Solutions (SPSS) software program was utilized to analysis the quantitative data. Mean values were calculated and interpreted for the individual items and sub-scales. For each item or subscale, the higher mean value implies that the participants have higher agreement rates or vice versa with that particular conception. Pearson productmoment correlation coefficient was applied to examine the direction and strength of the relationship among the dependent variables. This was done after preliminary analysis and assumptions of linearity and normality were performed; and correlation results were interpreted. The thematic analysis method was used as the primary method of analysis for the qualitative interview. The thematic analysis involved identifying, analyzing and documenting themes or trends within a data set (Braun \& Clarke, 2006).

\section{RESULTS}

\section{Basic School Teachers' Conceptions of Assessment}

The research question "What are the basic school teachers conceptions of classroom assessment in the Sissala East Municipality?" sought to explore the intentions of basic school teachers' in conducting classroom assessments. It specifically intended to expose their conception of classroom assessment and its degree. There are essentially four domains of conceptions of assessment. These are improving teaching and learning, making schools accountable, making students accountable for their learning and viewing assessment as irrelevant to teaching and learning (Brown, 2006). Descriptive statistics (frequency, mean, and standard deviation) were used 
to evaluate the responses of respondents for each sub-scale of the Teacher Conceptions of assessment Abridged Scale. The higher the mean rating of conception, the greater their agreement of the particular conception, which means that the study respondents are most likely to possess the conception. The standard deviation (SD) shows how widespread the agreement in the conception. The lower the value of SD, the higher the degree of agreement among the respondents. This implies that a teacher is very likely to have the conception if he or she is selected randomly from the study location on this particular conception. In contrast, when the spread of deviation becomes relatively large, means that the teachers are not homogenously sharing that conception.

All the items were rated according to participants' degree of agreement on a six-point Likert scale. The scale employed two negatives $(1=$ "strongly disagree" and $2=$ "mostly disagree") and four positive patterns ( $3=$ "slightly agree", $4=$ "moderately agree", $5=$ "mostly agree", and $6=$ "strongly agree"). The first two levela are classified as disagreement, and the other four are categorized as agreement. There was no reverse coding. Table 1 presents the overall results of assessment conception subscales.

As seen in Table 1, the conception subscales mean scores varied from 2.85 to 4.99 , indicating that some variability existed levels of assessment conceptions. Student accountability conception $(\mathrm{M}=4.99, \mathrm{SD}=.87)$ recorded the highest degree of rank and agreement among all the four assessment conception subscales and is followed by school accountability $(\mathrm{M}=4.84, \mathrm{SD}=.83)$ and improvement conception $(\mathrm{M}=4.74, \mathrm{SD}=.58)$. These three conceptions all have mostly agreement level. Irrelevance conception $(\mathrm{M}=$ $2.85, \mathrm{SD}=.72)$ reflected the lowest average score and is measured as a moderate disagreement level.

Table 1: Agreement Levels of Basic School Teachers Conception of Assessment

\begin{tabular}{|c|c|c|c|}
\hline Assessment conceptions subscales & $\mathrm{N}$ & $\mathrm{M}$ & $\mathrm{SD}$ \\
\hline Student Accountability & 203 & 4.99 & .87 \\
\hline School Accountability & 203 & 4.84 & .83 \\
\hline Improvement & 203 & 4.74 & .58 \\
\hline Irrelevance & 203 & 2.85 & .72 \\
\hline
\end{tabular}

The standard deviation indicated Student Accountability (SD $=.87$ ) had the greatest degree of variation followed by School Accountability $(\mathrm{SD}=.83)$. These imply that responses in these two conceptions are widely distributed from the grand mean. The two remaining subcategories, Improvement $(\mathrm{SD}=.58)$ and Irrelevance $(\mathrm{SD}=.72)$, showed limited variation compared to Student Accountability and School Accountability, with the Improvement conception recording the least degree of variation. The standard deviation in the improvement conception is the least among the four domains, which means that teachers' conception in this domain is much homogeneous among the respondents.
Table 2 indicates the results regarding assessment as holding students accountable for their learning. Table 2 reveals that the participants endorsed the student accountability conception. Concerning student accountability conception, the highest mean score reported was that assessment puts students into groups or categories $(\mathrm{M}=5.34, \mathrm{SD}=1.01)$. This implies the respondents mostly agree that assessment is used to classify students into various categories such as high, medium and low achievement levels. Likewise, the respondents mostly agree with the idea that assessment can be used to determine the extent to which students meet qualifications standards $(\mathrm{M}=$ $5.06, \mathrm{SD}=1.19)$.It can, therefore, be deduced that the teachers support the assessment roles of categorizing and certifying the performance of their students and thus support the conception that assessments make students responsible for their learning.

Table 2: Descriptive Statistics on Student Accountability Conception

\begin{tabular}{|c|c|c|c|c|}
\hline No & Item & $\mathrm{N}$ & $\mathrm{M}$ & $\mathrm{SD}$ \\
\hline 2 & Assessment places students into categories & 203 & 5.34 & 1.01 \\
\hline 20 & $\begin{array}{c}\text { Assessment determines if students meet } \\
\text { qualifications standards }\end{array}$ & 203 & 5.06 & 1.19 \\
\hline 11 & $\begin{array}{c}\text { Assessment is assigning a grade or level to } \\
\text { student work }\end{array}$ & 203 & 4.57 & 1.56 \\
\hline
\end{tabular}

Table 3 presents results on conceptions of classroom assessment by respondents for school accountability. As indicated in Table 3, concerning school accountability conception of assessment, the highest agreement was recorded with the assertion that "Assessment provides information on how well schools are doing" $(\mathrm{M}=5.27, \mathrm{SD}=1.13)$. This signifies that the basic school teachers "mostly agree" that assessment offers sufficient details about the schools' happenings and how well they are faring. Also, the respondents are slightly above a mostly disagreement level that assessment may also be used to check and measure schools' accomplishments $(\mathrm{M}=4.76, \mathrm{SD}=1.24)$. Item 10 "Assessment is an accurate indicator of a school's quality" recorded the lowest value $(\mathrm{M}=4.49, \mathrm{SD}=1.31)$. This score is considered to be a moderate agreement. Considering the range of mean values from 4.49 to 5.27 , it signifies that the basic school teachers supported the conception that assessment ensures the accountability of schools.

Table 3: Descriptive Statistics on Teacher's Conception with regards to School Accountability

\begin{tabular}{|c|c|c|c|c|}
\hline No & Item & N & M & SD \\
\hline 1 & $\begin{array}{c}\text { Assessment provides information on how } \\
\text { well schools are doing }\end{array}$ & 203 & 5.27 & 1.13 \\
\hline 19 & $\begin{array}{c}\text { Assessment is a good way to evaluate a } \\
\text { school }\end{array}$ & 203 & 4.76 & 1.24 \\
\hline 10 & $\begin{array}{c}\text { Assessment is an accurate indicator of a } \\
\text { school's quality }\end{array}$ & 203 & 4.49 & 1.31 \\
\hline
\end{tabular}

Table 4 depicts the results of respondents' conceptions regarding assessment as improving teaching and learning. As indicated in Table 5, with regards to the improvement conception, item 4 , recorded the highest mean score, followed 
by items 3 and 22 with mean values above 5.30. Item 4 mean value recorded was $(\mathrm{M}=5.55, \mathrm{SD}=.87)$, that is "Assessment provides feedback to students about their performance", and item 3 mean value $(\mathrm{M}=5.44, \mathrm{SD}=.97)$ that "Assessment is a way to determine how much students have learned from teaching." The third rank item is item 22 with a mean value of $(\mathrm{M}=5.32, \mathrm{SD}=1.00)$ that "Assessment helps students improve their learning."This means that most respondents conceived assessment to enhancestudent learning by providing the needed feedback on students' performance.

Again, as seen in Table 4, lower agreements were recorded for all items concerning assessment accuracy (items 15, 6 and 24). Item 15 recorded the lowest agreement value $(\mathrm{M}=3.13, \mathrm{SD}=$ 1.69) to the effect that "assessment results are consistent". This means that most respondents slightly disagree that assessment results are consistent. It must be noted that, apart from item 15, the rest of the items under this conception recorded a mean value above 4.10 . On the whole, the mean scores ranged from 3.13 to 5.55 , which implies that the basic school teachers viewed the purpose of assessment as improving teaching and learning. Hence, the respondents supported the improvement conception of assessment.

Table 4: Descriptive Statistics on Improvement Conception of Assessment

\begin{tabular}{|c|c|c|c|c|}
\hline No & Item & N & M & SD \\
\hline 4 & $\begin{array}{c}\text { Assessment provides feedback to students } \\
\text { about their performance }\end{array}$ & 203 & 5.55 & .87 \\
\hline 3 & $\begin{array}{c}\text { Assessment is a way to determine how } \\
\text { much students have learned from teaching }\end{array}$ & 203 & 5.44 & .97 \\
\hline 22 & $\begin{array}{c}\text { Assessment helps students improve their } \\
\text { learning }\end{array}$ & 203 & 5.32 & 1.00 \\
\hline 12 & $\begin{array}{c}\text { Assessment establishes what students have } \\
\text { learned }\end{array}$ & 203 & 5.09 & 1.01 \\
\hline 5 & $\begin{array}{c}\text { Assessment is integrated with teaching } \\
\text { practice }\end{array}$ & 203 & 5.06 & 1.02 \\
\hline 14 & $\begin{array}{c}\text { Assessment information modifies ongoing } \\
\text { teaching of students }\end{array}$ & 203 & 5.05 & 1.07 \\
\hline 13 & $\begin{array}{c}\text { Assessment feeds back to students learning } \\
\text { needs }\end{array}$ & 203 & 5.03 & 1.21 \\
\hline 21 & $\begin{array}{c}\text { Assessment measures students' higher-order } \\
\text { thinking skills }\end{array}$ & 203 & 4.70 & 1.24 \\
\hline 23 & $\begin{array}{c}\text { Assessment allows different students to get } \\
\text { different instruction }\end{array}$ & 203 & 4.21 & 1.54 \\
\hline 24 & Assessment results can be depended on & 203 & 4.13 & 1.36 \\
\hline 6 & Assessment results are trustworthy & 203 & 4.11 & 1.36 \\
\hline 15 & Assessment results are consistent & 203 & 3.13 & 1.69 \\
\hline
\end{tabular}

Table 5 indicates the results of the irrelevance conception. As observed in Table 6, under the irrelevance conception subscale, the basic school teachers moderately supported the assertion that "Assessment results should be treated cautiously because of measurement error" $(\mathrm{M}=4.38, \mathrm{SD}=1.50)$. Also, the teachers moderately endorsed the statement that "Teachers should take into account the error and imprecision in all assessment" of irrelevance conception ( $\mathrm{M}=4.37, \mathrm{SD}=1.61)$.
Table 5: Descriptive Statistics on Irrelevance Conception of Assessment.

\begin{tabular}{|c|c|c|c|c|}
\hline No & Item & $\mathrm{N}$ & $\mathrm{M}$ & $\mathrm{SD}$ \\
\hline 9 & $\begin{array}{c}\text { Assessment results should be treated } \\
\text { cautiously because of measurement error }\end{array}$ & 203 & 4.38 & 1.50 \\
\hline 18 & $\begin{array}{c}\text { Teachers should take into account the error } \\
\text { and imprecision in all assessment }\end{array}$ & 203 & 4.37 & 1.61 \\
\hline 8 & $\begin{array}{c}\text { Teachers conduct assessments but make } \\
\text { little use of the results }\end{array}$ & 203 & 2.89 & 1.49 \\
\hline 27 & Assessment is an imprecise process & 203 & 2.86 & 1.52 \\
\hline 7 & $\begin{array}{c}\text { Assessment forces teachers to teach in a } \\
\text { way against their beliefs }\end{array}$ & 203 & 2.67 & 1.63 \\
\hline 25 & Assessment interferes with teaching & 203 & 2.33 & 1.62 \\
\hline 17 & Assessment results are filed and ignored & 203 & 2.19 & 1.41 \\
\hline 16 & Assessment is unfair to students & 203 & 2.01 & 1.36 \\
\hline 26 & Assessment has little impact on teaching & 203 & 1.89 & 1.37 \\
\hline
\end{tabular}

Again, from Table 5, items 7, 8, and 27 recorded an average agreement of 2.63, 2.89 and 2.86, respectively. These values fell between mostly disagree and slightly agree according to the Likert scale used in this study. This shows that the respondents in this study slightly disagree that assessment is irrelevant as it "forces teachers to teach in a way against their beliefs", as teachers "conduct assessments but make little use of the results" and "assessment is an imprecise process." Four remaining items (items $26,16,17,25$ ) received a low-value range from 1.89 to 2.23 . This shows that, in this research, the teachers do not firmly believe that assessment is of no value and hence view assessment as realistic and utilized to inform the value of teaching and learning.

\section{Relationship between Teachers' Conceptions of Assessment Categories}

The research question "Are they any relationship among the teachers' conception of assessment?" sought to explore the relationships that existed among the conceptions of assessment the teachers hold.A Pearson Correlation analysis was conducted to examine whether the conceptions of assessment categories are interrelated. Table 6 shows the relationships using the Pearson correlation coefficient between different levels of assessment conceptions.

Table 6: Correlations among Teacher Conceptions of Assessment ( $\mathrm{N}=203)$

\begin{tabular}{|c|c|c|c|c|}
\hline Conceptions subscales & 1 & 2 & 3 & 4 \\
\hline Student Accountability & 1 & & & \\
\hline School Accountability & $.55^{* *}$ & 1 & & \\
\hline Improvement & $.49^{* *}$ & $.53^{* *}$ & 1 & \\
\hline Irrelevance & -.05 & -.06 & -.13 & 1 \\
\hline
\end{tabular}

$* * \mathrm{p}<0.01$ (2-tailed).

The strength of the relationships was determined using Cohen's norm, coefficients between .10 and .29 signalling a small effect size, coefficients between .30 and .49 denoting a moderate effect size, and coefficients above .50 indicating a large effect size (Cohen, 1988). The results of the analysis indicated a significant positive correlation between Student 
Accountability and School Accountability $(r=0.55, p<.001)$. The coefficient between Student Accountability and School Accountability was 0.55 , representing a large effect size. This relationship shows that as Student Accountability increases, School Accountability tends to increase. Likewise, a significant positive correlation was recorded between Student Accountability and Improvement conceptions $(r=0.49, p<$ .001). The Student Accountability and Improvement correlation coefficient was 0.49 , denoting a moderate effect size. This shows that Student Accountability tends to increase as Improvement increases. Also, Improvement and School Accountability were significantly positively correlated ( $\mathrm{r}=$ $0.53, \mathrm{p}<.001)$. The coefficient of correlation between Improvement and School Accountability was 0.53, which suggests a large effect size. This correlation suggests that School Accountability tends to increase as Improvement increases. Additionally, the Irrelevance assessment conceptionwas found to be negatively correlated with the Student Accountability conception $(r=-.05)$, School Accountability conception $(r=.-.06)$, and Improvement conception $(r-.13)$. These relationships were not significant.

\section{Interview Results}

As a follow-up on basic teachers' conception of classroom assessment, twelve (12) basic school teachers were interviewed. Out of the twelve teachers selected, four were teaching at the lower primary, three at the upper primary and five at the Junior High School. In terms of gender, six were females and six males. To hide the identities of the interviewees, each of them has been given a false name. Besides, the abbreviation LPT, followed by a number in the write-up, gives the identity of participant teaching at lower primary, while UPT followed by a number in the write up also identifies the respondent as teaching at upper primary and finally, JHT followed by a number in the write up is an identity of a Junior High School teacher respondent. For example, LPT 1 means first lower primary school teacher interviewee, UPT 2 means second upper primary teacher interviewee and JHT 3 means third Junior High School teacher interviewee. The results of the interview are presented below.

Question: What, in your opinion, is the purpose of classroom assessment?

This question was intended to obtain respondents' views about the purpose of classroom assessment. It was evident from the responses that the majority (six) of the interviewees conceived classroom assessment as an instrument that serves formative purposes for improving teaching and learning.

From the responses, the main themes emanating from the interviews were classroom assessment as a mechanism to hold pupils accountable for learning, ensuring school quality and compliance and improving teaching and learning. Specifically, three out of five teachers who held accountability assessment conception at the survey stage, their responses during the interview show that they believed that assessment ensures that pupils are made to account for their learning and depicts the quality of teachers and schools. The following excerpts are some typical responses:

For me, I view the purpose of assessment to ensure that students are kept on their toes to learn. You see, students are such that if you teach them without assessing them, they will not learn (Najo, JHST 1, Interviewed data, 2020).

Errrrr, the purpose of assessment is to find out whether the students have been able to accomplish the standard set out for them (Salma, JHT 2, Interviewed data, 2020).

The purpose of assessment is to find out how best teaching is taking place in the school (Samad, UPT 1, Interviewed data, 2020).

However, the remaining two, who are both female teachers and teaching at the lower primary, held a mixed conception of improvement and accountability. The following are the excerpts of their responses:

I see the main purpose of assessment as a means use to verify the effectiveness of our teaching methods and also to provide information to parents of the performance of their children (Atika, LPT 1, Interviewed data, 2020).

Assessment enables teachers to know how much their students have understood their lessons and also use to categorize students into their abilities (Diana, LPT 2, Interviewed data, 2020).

Also, regarding the improvement conception, those identified to belong to this domain believed that assessment was a vital part of teaching and learning. This cluster of teachers believed that assessment is a mechanism to establish what students have learned and identify the students' strengths and weaknesses. It is also a means to finding out how effective one's teaching is. The following excerpts are some typical responses:

Ok, emmm, to me, the purpose of assessment is to know how well the pupils understood the lesson delivered and the accuracy of the teacher's methodology applied in delivering the lesson (Rose, LPT 1, Interviewed data, 2020).

Well, the purpose of assessment to me, errrr is to improve students learning, and teachers' teaching as both the students and teachers are involved in the process of assessment (Moses UPT 2, Interviewed data, 2020).

Personally, assessment enables teachers to diagnose our students learning needs so that we can plan and teach to suit such needs (Fauzia, JHT 3, Interviewed data, 2020).

Surprisingly, none of the three irrelevance cluster participants did express any view to show that assessment is irrelevant. Rather two of them conceived assessment as 
making students accountable and the remaining one as supporting teaching and learning. The following excerpts are their responses.

To me, the purpose of assessment is to provide evidence of the extent to which students are learning (Kojok, JHT 5, Interviewed data, 2020).

To me, assessment confirms that a learner has gained knowledge and can prove his or her competencies and skills (Dimbie, UPT 3, Interviewed data, 2020).

The purpose of assessment to me is to inform students of their progress and also teachers about how hard they need to work for their students to progress (Halitie, LPT 3, Interviewed data, 2020).

The results revealed that out of 12 respondents selected from the three conceptions clusters, six viewed the purpose of assessment for improvement of teaching and learning, four as for accountability purposes, and the remaining two held a mixed conception of improvement and accountability. These results confirm the quantitative results, as it has been demonstrated that the teachers hold a mixed conception of assessment. However, whereas in the quantitative results, accountability purposes of assessment held the highest priority, in the qualitative results, the majority of the participants held an improvement conception of assessment. This is not surprising because, in the quantitative results, the standard deviation in the improvement conception is the least among the four domains, which means that teachers' conception in this domain is much homogeneous among the respondents. This means that the teachers in this sample approved the improvement and accountability conceptions. Again, the high rating of the student and school accountability conceptions could also be due to the number of items used to measure them in the survey. For instance, whereas three (3) items each were used to measure the student and school accountability conceptions, twelve (12) were used to measure the improvement conception.

\section{DISCUSSIONS OF RESULTS}

The question "What are the basic school teachers' conceptions of classroom assessment in the Sissala East Municipality?" sought to unearth participants' purposes of conducting classroomassessment. Consideration was given to four levels of conception; student accountability, school accountability, improvement, and irrelevance. The respondents supported the belief that assessment improves teaching and learning, ensures students accountability and enhances school accountability. The descriptivestatistics in the quantitative results indicated that the student accountability conception of assessment recorded the topmost mean valueamongst all four assessment conceptions categories of $(M=4.99, S D=.87)$. This was followed by school accountability $(\mathrm{M}=4.84, \mathrm{SD}=.83)$, improvement $(\mathrm{M}=4.74, \mathrm{SD}=.58)$ and irrelevance $(\mathrm{M}=2.85$, $\mathrm{SD}=.72$ ). This means that the respondents mostly agreed with the student accountability, school accountability and improvement conceptions of assessment. The qualitative results revealed that the teachers in Sissala East Municipality conceived assessment as a mechanism for holding students accountable for learning, ensuring teacher and school effectiveness and improving teaching and learning. Invariably, these results are saying that these teachers hold a mixed conception of improvement and accountability. Thus, teachers who perceive assessment as improvement are also probable to conceive that assessment is linked with student and school accountability. According to Brown (2004), improvement and accountability conceptions are typically intertwined, primarily as every teacher disproportionately holds some percentage of both conceptions. The study finding of a mixed conception of assessment is similar to previous studies by Azis (2014) where teachers held a mixed conception but with improvement conception being primary and accountability secondary.

However, in this present study, whereas in the quantitative results, accountability purposes of assessment held the highest priority, in the qualitative results, the majority of the participants held an improvement conception of assessment. The variations in Azis (2014) findings in relation to this study, can be due to variations in methods of research applied and, in the teaching, and learning contexts. Moreover, differences in findings may also be due to the use of the original teachers' conception of assessment questionnaire by Brown, which contains 53 items in his study compared to the current study use of the abridged version which contains 27 items. Nonetheless, in this study quantitative results, the standard deviation in the improvement conception was the least among the four domains, which means that teachers' conception in this domain is much homogeneous among the respondents. This means that the teachers in this sample endorsed the accountability and improvement conceptions.

Also, the findings of the quantitative aspect of this research were found to correlate with other studies. For example, Vardar (2010) examined sixth to eighth-grade Turkish teachers' $(n=414)$ assessment conceptions using the TCoAIIIA and revealed that the teachers held students' accountability conceptions as the utmost priority. Vadar (2010) attributed this to the Turkish high-stakes education culture that puts students in a competitive manner in obtaining higher grades examinations. This is also true in the Ghanaian case, as the educational system is characterized by high-stakes examination. Moreover, the student accountability conception view was supported by Yidana and Anti Partey (2018) study on economics teachers' conceptions of assessment where student accountability conception recorded the highest mean value with most Economics teachers using classroom assessment as a mechanism to categorize learners. They noted that teachers held this view because the "Economics teachers were once students and subjected to rigorous assessment exercises" (p.168).

Furthermore, correlation results indicated that student accountability conception was strongly correlated with school accountability $(\mathrm{r}=.55, \mathrm{p}<.001)$ and moderately correlated 
with improvement $(\mathrm{r}=.49, \mathrm{p}<.001)$ conceptions. Also, school accountability was strongly correlated with Improvement conception $(\mathrm{r}=.53, \mathrm{p}<.001)$. Thus, a moderate relationship existed among student accountability, school accountability and improvement, and that these levels affect each other positively. Thus, the more a teacher conceives assessment as improving teaching and learning, the more the teacher believed that assessment ensures students, teachers and schools are accountable.

These findings are in line with Yetkin's (2017) findings, where he found that the correlations between improvement, student accountability and school accountability were positive and significant. Moreover, Vardar (2010) unearthed that all three conceptions were moderately associated except Irrelevance conception which had non-significant relationships with the others. This implies that the teachers "conceived of assessment as assigning a grade or placing students into categories in order to increase their students' scores in assessments" (Vadar, 2010, p. 69).

Similar findings can be explained by the realities and cultural norms of the competitive Ghanaian education system where parents demand accountability from their wards, teachers and schools. This indicates that assessment should promote and ensure accountability in the teaching and learning process. With this, Yates and Johnson (2017) noted that the teachers somewhat endorsed the "notion that school quality can be measured through assessment results, in particular when those assessments are also used to award qualifications" (p.11).

The lower composite means connected with the conception of irrelevance assessment will suggest a relatively neutralendorsement. Means and standard deviations ( $\mathrm{M}=$ $2.85, \mathrm{SD}=.72$ ) for the irrelevance subgroup indicate that the teachers heldmarginally neutral views of this conception as variation in mean responses fellbetween slightly agree and slightly disagree. However, findings from the qualitative results revealed that teachers did not find assessment irrelevant. Moreover, the Irrelevance assessment conceptionwas found to be negatively correlated with the Student Accountability conception $(r=-.05)$, School Accountability conception ( $r=.-.06)$, and Improvement conception $(r-.13)$. These relationships were not significant. These findings are also consistent with Vardar's (2010) and Yetkin (2017) studies that irrelevance conception has not had any meaningful relationship with the other conceptions of assessment subcategories.

\section{VI.CONCLUSIONS}

The conclusions drawn from this study are as follows. First, the study brought to light that study participants exhibited positive conceptions of assessment of ensuring student and school accountability and improving teaching and learning. Thus, the participants possessed a mixed-conception of improvement and accountability. Second, the relationships among student accountability, school accountability and improvement were moderate, and these levels positively affected each other. Thus, the more a teacher conceives assessment as improving teaching and learning, the more the teacher believed that assessment ensures students, teachers and schools are accountable. The student and school accountabilities role in the basic school teachers' conceptions of assessment can be explained by the competitiveness of the Ghanaian educational system where high-level testing plays an essential role in the students' future advancement and places schools in ranks ranging between most successful and less successful. However, the respondents did downplay classroom assessment conception of irrelevance, which is considered undermining the teachers' professional autonomy in certain contexts.

\section{VII.RECOMMENDATIONS}

Based on the key conclusions of this study, it is recommended that:

a. The Ministry of Education should coordinate and update assessment procedures by taking account of improvement conception and school and student accountabilities.

b. Both policymakers and teachers need to note that assessment is acceptable if motivated by a particular reason, whether for improvement, student accountability, or school accountability.

\section{SUGGESTIONS FOR FURTHER RESEARCH}

The implications of this study's results warrant further work in the field of classroom assessment. The following are recommended for further research:

1. Similar research is recommended to be carried out in other districts in the Upper West Region and other areas of Ghana. This will provide the basis for a more comprehensive inference to be drawn on the conceptions of classroom assessment of basic school teachers.

2. In addition to the in-service teachers, the conceptions of preservice teachers, students, and school heads should also be investigated to link the findings to give a more detailed view of assessment conceptions.

\section{REFERENCES}

[1] Agyedu, G. O. Donkor, F., \& Obeng, S. (2013). Teachyourself research methods. Amakom-Kumasi: Payless Publication Limited.

[2] Amedahe, F. K. (1989). Testing practices in secondary schools in the central region of Ghana. Unpublished master's thesis, University of Cape Coast, Cape Coast.

[3] Amoako, I. (2018). Formative assessment practices among distance education tutors in Ghana. African Journal of Teacher Education, 7(3), 22 -36.

[4] Anhwere, Y. M. (2009). Assessment practices of teacher training college tutors in Ghana. Unpublished master's thesis, University of Cape Coast, Cape Coast.

[5] Asare, K. (2015). Exploring the kindergarten teachers' assessment practices in Ghana. Developing Country Studies, 5(8), 2225-0565.

[6] Azis, A. (2014) Indonesian junior secondary school teachers' conceptions of assessment: A mixed methods study (Doctoral 
Thesis, The University of Wellington, New Zealand). Retrieved from http://researcharchive.vuw.ac.nz/xmlui/handle/10063/320

[7] Azis, A. (2015). Conceptions and practices of assessment: A case of teachers representing improvement conception. TEFLIN Journal, 26(2), 129-154.

[8] Barnes, N., Fives, H., \& Dacey, C. M. (2015). Teachers' beliefs about assessment. In H. Fives, \& M. G. Gill (Eds.), The handbook of research on teachers' beliefs (pp. 229 - 233). New York, NY: Routledge.

[9] Barnes, N., Fives, H., \& Dacey, C. M. (2017). U.S. teachers' conceptions of the purposes of assessment. Teaching and Teacher Education, 65, $107-116$.

[10] Bekoe, S. O., Eshun, I., \&Bordoh, A. (2013). Formative assessment techniques tutors use to assess teacher-trainees' learning in Social Studies in Colleges of Education in Ghana. Research on Humanities and Social Sciences, 3(4), 20-30.

[11] Bordoh, A., Bassaw, T. K., \&Eshun, I. (2013). Social Studies tutors' cognition in formative assessment in colleges of education in Ghana. Development Country Studies, 3(11), 1-11.

[12] Braun, V. \& Clarke, V. (2006) Using thematic analysis in psychology. Qualitative Research in Psychology, 3(2), 77-101.

[13] Brown, G. T. L. (2002). Teachers' conceptions of assessment. Dissertation. University of Auckland, NZ. Auckland.

[14] Brown, G. T. L. (2004). Teachers' conceptions of assessment: Implications for policy and professional development. Assessment in Education: Policy, Principles and Practice, 11(3), 305-322.

[15] Brown, G. T. L. (2006). Teachers' conceptions of assessment: Validation of an abridged instrument. Psychological Reports,99, 166-170.

[16] Brown, G. T. L. (2008). Conceptions of assessment: Understanding what assessment means to teachers and students. Nova Science Publishers.

[17] Brown, G. T. L. (2009). Teachers' self-reported assessment practices and conceptions: Using structural equation modelling to examine measurement and structural models. In T. Teo \& M. S. Khine (Eds.), Structural equation modelling in educational research: Concepts and applications (pp. 243-266). Rotterdam, NL: Sense Publishers.

[18] Brown, G. T. L. (2011).New Zealand prospective teacher conceptions of assessment and academic performance: Neither student nor practicing teacher. In R. Kahn, J. C. McDermott, \& A. Akimjak (Eds.), Democratic access to education (pp.119 - 132). Los Angeles, CA: Antioch University Los Angeles, Department of Education.

[19] Brown, G. T. L., \& Gao, L. (2015). Chinese teachers' conceptions of assessment for and of learning: Six competing and complementary purposes. Cogent Education, 2(1), 1-19.

[20] Brown, G. T. L., \& Harris, L. R. (2009). Unintended consequences of using tests to improve learning: How improvement-oriented resources heighten conceptions of assessment as school accountability. Journal of Multidisciplinary Evaluation, 6(12), 6891.

[21] Brown, G. T. L., \& Hirschfeld, G. H. F. (2008). Student' conceptions of assessment: Links to outcomes. Assessment in Education: Principles, Policy and Practice, 15(1), 3 - 17.

[22] Brown, G. T. L., \&Michaelides, M. P. (2011). Ecological rationality in teachers' conceptions of assessment across samples from Cyprus and New Zealand. European Journal of Psychology of Education, 26(3), 319-337. doi:10.1007/s10212-010-0052-3

[23] Brown, G. T. L., Chaudhry, H., \& Dhamija, R. (2015). The impact of an assessment policy upon teachers' self-reported assessment beliefs and practices: A quasi-experimental study of Indian teachers in private schools. International Journal of Educational Research,71, doi:http://doi.org.dcu.idm.oclc.org/10.1016/j.ijer.2015.03.001

[24] Brown, G. T. L., Hui, S.K.F., Yu, F. W. M., \& Kennedy, K. J. (2011). Teachers' conceptions of assessment in Chinese contexts: A tripartite model of accountability, improvement, and irrelevance. International Journal of Educational Research, 50, 307-320. doi: 10.1016/j.ijer.2011.10.00.
[25] Brown, G. T. L., Kennedy, K. J., Fok, P. K., Chan, J. K. S., \& Yu, W. M. (2009). Assessment for student improvement: Understanding Hong Kong teachers' conceptions and practices of assessment. Assessment in Education: Principles, Policy \& Practice, 16(3), 347-363. DOI: 10.1080/09695940903319737

[26] Brown, G. T. L., Lake, R. \& Matters, G. (2011). Queensland teachers' conceptions of assessment: The impact of policy priorities on teacher attitudes. Teaching and Teacher Education, 27, 210-220. doi: 10.1016/j.tate.2010.08.003

[27] Brown, G. T. L., Lake, R., \& Matters, G. (2009). Assessment policy and practice effects on New Zealand and Queensland teachers' conceptions of teaching. Journal of Education for Teaching, 35(1), 61-75. doi: 10.1080/02607470802587152

[28] Calveric, S. B. (2010). Elementary teachers' assessment beliefs and practices. (Doctoral dissertation, Virginia Commonwealth University, Virginia, USA).

[29] Cohen, J. (1988). Statistical power analysis for the behaviour sciences (2nd ed.). St. Paul, MN: West Publishing Company.

[30] Cohen, L., Manion, L \& Morrison, K. (2018). Research methods in education (8thed.). New York: Routledge.

[31] Creswell, J. W. \& Creswell, D. J. (2018). Research design: Qualitative, quantitative and mixed methods approaches (5thed.). Thousand Oaks, California: SAGE Publications Inc.

[32] Creswell, J. W., \& Plano Clark, V. L. (2018). Designing and conducting mixed methods research (3rd ed.). Thousand Oaks: Sage Publications.

[33] Darmody, M. (2017). Irish post-primary teachers' conceptions of assessment. Dissertation, Institute of Education, Dublin City University.

[34] Davis, D. S., \&Neitzel, C. (2011). A self-regulated learning perspective on middle grades classroom assessment. Journal of Educational Research, 104, 202-215.

[35] Dayal, H. C., \& Lingam, G. I. (2015). Fijian teachers' conceptions of assessment. Australian Journal of Teacher Education, 40 (8), 27 - 46.http://dx.doi.org/10.14221/ajte.2015v40n8.3

[36] Earl, L. (2003). Assessment as learning: Using classroom assessment to maximize student learning. Thousand Oaks, CA: Corwin Press.

[37] Eshun, I., Bordoh, A., Bassaw, T. K. \& Mensah, (2014). Evaluation of social studies students' learning using formative assessment in selected colleges of education in Ghana. British Journal of Education, 2(1), 39-48.

[38] Fulmer, G. W., Tan, K. H. K., \& Lee, C. H. I. (2017): Relationships among Singaporean secondary teachers' conceptions of assessment and school and policy contextual factors. Assessment in Education: Principles, Policy \& Practice, 1 - 17. http://dx.doi.org/10.1080/0969594X.2017.1336427

[39] Gebril, A., \& Brown, G. T. L. (2014). The effect of high-stakes examination systems on teacher beliefs: Egyptian teachers' conceptions of assessment. Assessment in Education: Principles, $\begin{array}{llll}\text { Policy } \quad \text { \& } & \text { 21(1), }\end{array}$ doi:10.1080/0969594X.2013.831030

[40] Harris, L. (2008). Secondary teachers' conceptions of the purpose of assessment and feedback. Paper presented to the Australian Association for Research in Education (AARE) Annual Conference, December 2008, Brisbane, Australia.

[41] Harris, L. R., \& Brown, G. T. L. (2009). The complexity of teachers' conceptions of assessment: Tensions between the needs of schools and students. Assessment in Education: Principles, Policy, \& Practice, 16(3), $365-381$.

[42] Krejcie, R. V. \& Morgan, D.W. (1970). Determining sample size for research activities. Educational and Psychological Measurement,30, 607-610.

[43] Moiinvaziri, M. (2015). University teachers' conception of assessment: A structural equation modelling approach. Journal of Language, Linguistics and Literature, 1(3), 75-85.

[44] Nafiu, L. A. (2012). Comparison of one-stage, two-stage, and three-stage estimators using finite population. The Pacific Journal of Science and Technology, 13(2), 166-171.

[45] National Council for Curriculum and Assessment (NaCCA) (2019). Resource guide for the orientation of primary school 
teachers towards the implementation of the revised curriculum for primary schools. Accra: Ministry of Education.

[46] Neuman, W. L. (2014). Social research methods: Qualitative and quantitative approaches (7thed.). Harlow: Pearson Education Limited.

[47] Okyere, M. \& Larbi, E. (2019). Senior high school mathematics teachers' perception and use of assessment in the classroom. African Journal of Educational Studies in Mathematics and Sciences, 15(2), $43-54$.

[48] Opre, D. (2015). Teachers' conceptions of assessment. ProcediaSocial and Behavioural Sciences, 209, 229-233.

[49] Remesal, A. (2007). Educational reform and primary and secondary teachers' conceptions of assessment: The Spanish instance, building upon Black and Wiliam (2005). The Curriculum Journal, 18(1), 27-38.doi: 10.1080/09585170701292133

[50] Remesal, A. (2011). Primary and secondary teachers' conceptions of assessment: A qualitative study. Teaching and Teacher Education, 27, 472-482.

[51] Segers, M., \&Tillema, H. (2011). How do Dutch secondary teachers and students conceive the purpose of assessment? Studies in Educational Evaluation ,37(1), 49-54.

[52] Sethusha, M. J. (2012). Primary school teachers' conceptions of classroom assessment: A qualitative Study. International Journal for Cross-Disciplinary Subjects in Education (IJCDSE), 3(2), 699 -706 .

[53] Sofo, S., Ocansey, R. T., Nabie, M. J. \&Asola, E. F. (2013). Assessment practices among secondary physical education teachers in Ghana. International Online Journal of Educational Sciences, 5(2), 274-281.

[54] Thompson, A. (1992). Teachers' beliefs and conceptions: A synthesis of the research. In D. A. Grouws (Ed.), Handbook of research on mathematics teaching and learning (pp. 127-146). New York: McMillan

[55] Vardar, E. (2010). Sixth, seventh, and eighth grade teachers' conception of assessment. (Master's Thesis, Middle East Technical University, Ankara, Turkey).

[56] Xu, Y., \& Brown, G. T. L. (2016). Teacher assessment literacy in practice: A reconceptualization. Teaching and Teacher Education, $58(2), 149-162$

[57] Yates, A., \& Johnston, M. (2017). The impact of school-based assessment for qualifications on teachers' conceptions of assessment. Assessment in Education: Principles, Policy \& Practice, 1-17. doi:10.1080/0969594X.2017.1295020

[58] Yetkin, R. (2017). Pre-service English teachers' conception of assessment and their future assessment practices in a Turkish context. Master's thesis. Hacettepe University.

[59] Yetkin, R. (2018). Exploring prospective teachers' conceptions of assessment in Turkish context. European Journal of Education Studies, 4(5), 133-146. DOI: 10.5281/zenodo.1230554

[60] Yidana, M. B. \& Anti Partey, P. (2018). Economics teachers' conceptions of classroom assessment: A study of senior high schools in the Central and Ashanti Regions of Ghana. International Journal for Innovation Education and Research, 6(10), $\quad 153 \quad-\quad 174 . \quad$ DOI: https://doi.org/10.31686/ijier.Vol6.Iss10.1176 